\title{
IMPLIKASI EKSTRAKURIKULER KARATE PADA ANAK SEKOLAH DASAR DI MASA PANDEMI COVID-19 (Studi Kasus Perguruan Dojo Cakrawala Institut Karate-Do Indonesia)
}

\author{
Panca Kumala Dewi ${ }^{1}$, Nur Hadi ${ }^{2}$, Joan Hesti Gita Purwasih ${ }^{3}$ \\ 'Prodi Pendidikan Sosiologi, Universitas Negeri Malang \\ Corresponence email: pancadewi445@gmail.com \\ ${ }^{2}$ Prodi Pendidikan Sosiologi, Universitas Negeri Malang \\ Corresponence email: nur.hadi.fis@um.ac.id \\ 3 Prodi Pendidikan Sosiologi, Universitas Negeri Malang \\ Corresponence email: joan.hesti.fis@um.ac.id
}

\begin{abstract}
Learning and extracurricular activities in schools have not been able to run optimally, because of the online learning regulations during the Covid-19 pandemic which required students and teachers to learn and teach online. This study aims to analyze the impact of online learning policies for elementary school and the effectiveness of extracurricular implementation outside of school during the Covid-19 pandemic. This research uses qualitative research methods and a case study approach which is carried out at the Dojo Cakrawala INKAI college, Malang City. The results of this study were obtained from the results of the interview analysis including one sensei or teacher in college, six parents of students and three students who practiced at the Dojo Cakrawala. The unit of analysis uses the AGIL Talcott Parsons functionalist theory. The results showed that there was a dysfunction between government policies regarding online learning which made elementary school students experience obstacles in carrying out physical activities in school learning. Additional activities such as extracurricular activities outside of school can be a solution for children to learn to make good use of time so that they can optimize mental, physical, psychological, motor development, and can reduce children's boredom in the face of online learning so that they can still excel even in pandemic conditions.
\end{abstract}

Keywords :

Extracurricular; karate, online learning.

\begin{abstract}
Abstrak
Pembelajaran dan ekstrakurikuler disekolah belum dapat berjalan secara maksimal, sebab adanya peraturan pembelajaran daring di masa pandemi Covid-19 yang mengharuskan siswa dan guru melakukan belajar dan mengajar secara daring. Penelitian ini bertujuan untuk menganalisis dampak kebijakan belajar daring bagi anak sekolah dasar dan efektifitas pelaksanaan ekstrakurikuler di luar sekolah selama pandemi Covid-19. Penelitian ini menggunakan metode penelitian kualitatif dan pendekatan studi kasus yang dilaksanakan di perguruan Dojo Cakrawala INKAI Kota Malang. Hasil penelitian ini diperoleh dari hasil analisis wawancara meliputi satu sensei atau guru dalam perguruan, enam orang tua siswa dan tiga siswa yang latihan di dojo cakrawala. Unit analisisnya menggunakan teori fungsionalis AGIL Talcott Parsons. Hasil penelitian menunjukkan bahwa adanya disfungsi antara kebijakan pemerintahh mengenai pembelajaran daring yang membuat siswa sekolah dasar mengalami hambatan dalam melakukan aktivitas fisik dalam pembelajaran disekolah. Kegiatan tambahan seperti ekstrakurikuler diluar sekolah dapat sebagai solusi untuk anak belajar memanfaatkan waktu dengan baik sehingga dapat mengoptimalisasikan perkembangan mental, fisik, psikis, motorik, dan dapat mengurangi tingkat kejenuhan anak dalam menghadapi pembelajaran daring sehingga mereka tetap berprestasi meskipun dalam kondisi pandemi.
\end{abstract}

Kata Kunci :

Ekstrakurikuler; karate; pembelajaran daring. 


\section{A. PENDAHULUAN}

Dunia dirisaukan dengan adanya persebaran (Covid-19) yang berasal dari negara Cina kota wuhan pada tahun 2019. Pandemi Covid-19 ini telah melumpuhkan kegiatan pada segala sektor kehidupan seperti pendidikan, sosial, ekonomi dll.

Pandemi Covid-19 diartikan sebagai virus yang menyerang pada saluran pernafasan, umumnya gejala yang terlihat seperti orang terkena flu pada umumnya. Namun, tingkat penularan virus ini sangat cepat dan dapat mengakibatkan kematian'1. Covid19 baru diketahui ada di Indonesia pada awal bulan Maret 2020 setelah presiden Joko Widodo secara langsung mengumumkan adanya pandemi secara resmi pada 2 Maret $2020^{2}$

Setelah diumumkannya adanya WNI yang terjangkit virus covid-19 pemerintahh Indonesia tidak langsung tanggap dalam membuat kebijakan mengenai peraturan menjaga kesehatan atau sosial distancing sehingga penyebaran virus corona di Indonesia sangat pesat. Akibat angka penularan Covid-19 yang signifikan setiap harinya pemerintahh mengambil kebijakan untuk menggeluarkan kebijakan darurat seperti Peraturan Nomor 21 Tahun $2020^{3}$ yang membahas mengenai pembatasan sosial bersekala besar kebijakan ini dinilai efektif pada situasi

\footnotetext{
1 Nur Rohim Yunus and Annissa Rezki, "Kebijakan Pemberlakuan Lock Down Sebagai Antisipasi Penyebaran Corona Virus Covid-19," SALAM: Jurnal Sosial Dan Budaya Syar-I 7, no. 3 (2020): 227-38, https://doi.org/10.15408/sjsbs.v7i3.15083.

2 "Pengumuman Mendadak Jokowi Yang Kejutkan Pasien Positif Corona... Halaman All Kompas.Com," accessed March 1, 2021, https://nasional.kompas.com/read/2020/o3/o4/ o8051361/pengumuman-mendadak-jokowiyang-kejutkan-pasien-positif-corona?page=all. 3 Presiden Republik Indonesia, "Peraturan Pemerintahh Nomor 21 Tahun 2020 Tentang
}

seperti ini guna mencegah penularan lebih masif. Kebijakan pembatasan sosial sejalan dengan peraturan nomor 21 Tahun 2020 pasal 4 yang membahas mengenai peliburan sekolah dan semua tempat yang sifatnya membuat kerumunan dan berpotensi pada persebaran virus ini. Sejalan dengan kebijakan pemerintahh pusat kemendikbud merespon dengan membuat kebijakan sekolah yang dilakukan secara online/daring. Kemendikbud membaca bahwa apabila sekolah dilakukan secara luring dapat berpotensi besar pada penularan virus ini mengingat dalam satu kelas siswa bisa mencapai 30 anak. Menurut Surat Edaran Nomor:

36962/MPK.A/HK/2020 4 , tanggal 17 Maret 2020 yang berisi mengenai WFH atau wsork from home dan sekolah daring.

Kebijakan yang dilakukan baik
dari pemerintahh maupun kemendikbud pasti mendapatkan pro dan kontra, tujuan kemendikbud yang memprioritaskan kesehatan dalam masa pandemi ini di respon positif oleh sebagian besar sekolah di Kota Malang karena situasi dan pemberitaan yang sangat mengerikan baik dari media maupun dari pemerintahh. Adanya kebijakan ini sangat direspon positif diawal persebaran corona di Indonesia sepertihalnya sebagian besar sekolah

Pembatasan Sosial Berskala Besar Dalam Rangka Percepatan Penanganan Coronavirus Disease 2019/COVID-19” 2019, no. 022868 (2020): 8.

${ }^{4}$ Kemendikbud, "SE Mendikbud: Pembelajaran Secara Daring Dan Bekerja Dari Rumah Untuk Mencegah Penyebaran Covid-19," Kementerian Pendidikan dan Kebudayaan Republik Indonesia, 2020, https://www.kemdikbud.go.id/main/blog/2020 /o3/se-mendikbud-pembelajaran-secaradaring-dan-bekerja-dari-rumah-untukmencegah-penyebaran-covidig. 
\begin{tabular}{lccc} 
serentak & engan & \multicolumn{2}{c}{ melakukan } \\
pembelajaran & secara & daring dan \\
meniadakan & kegiatan & tatap muka \\
disekolah. & & &
\end{tabular}

Tidak hanya Kota Malang yang meniadakan kegiatan pembelajaran dengan tatap muka, namun ada banyak sekolah yang melakukan work from home sekitar 68 juta siswa yang sekolah secara daring dirumah, dan kurang lebih sebanyak empat juta guru yang harus bekerja dari rumah ${ }^{5}$. Kebijakan WFH yang awalnya direspon positif ternyata menimbulkan berbagai macam polemik bagi orang tua dan siswa dalam melakukan aktivitas belajar dan mengajar. Kebiasaan baru dalam belajar menggunakan gawai membuat sebagian besar siswa sekolah dasar kecanduan bermain gawain seperti bermain game atau youtube. Melihat habit anak sekolah dasar sekarang cenderung lebih suka menghabiskan waktu dengan bermain gawai sehingga anak sekolah dasar jaman sekarang cenderung memiliki sifat cuek, kurang peka, tidak peduli dengan lingkungan dan etika atau sopan santunnya mengalami degenerasi.

Melihat banyaknya dampak dari perubahan sistem belajar dan mengajar orang tua wali murid memilih alternatif lain agar anaknya dapat memanfaatkan waktu dengan baik dan tidak kecanduan bermain gawai seperti dengan mendaftarkan anak untuk mengikuti ekstrakurikuler diluar sekolah. Berdasarkan kutipan dari jurnal Moh. Uzer Usman yang menjelaskan bahwa ekstrakurikuler didefinisikan sebagai

\footnotetext{
5 Kemendikbud.

6 Oteng Sutisna, "Landasan Teori Kegiatan Ekstrakurikuler,” Journal of Chemical Information and Modeling 53, no. 9 (2019): 168999.

7 Jurnal Pendidikan Dasar, Jurnal Tunas Nusantara, and Queen Elvina Sevtivia Asrivi,
}

kegiatan yang bisa dilakukan baik di sekolah maupun diluar sekolah. Ekstrakurikuler sendiri bertujuan untuk memperluas wawasan, mengajarkan etika dan sopan santun, dan mengasah kecerdasan dasar anak sehingga anak dapat mengembangkan bakat yang sudah dimilikinya ${ }^{6}$.

Sedangkan jika dilihat dari tujuan ekstrakurikuler yang bertujuan mendidik anak untuk berkarakter, cerdas dan berprestasi itu tidak dapat dipisahkan dalam kurikulum pendidikan di Indonesia. Kegiatan ekstrakurikuler selain memiliki tujuan diatas juga dapat berfungsi sebagai alternatif untuk mengembangkan minat peserta didik yang tidak didapatkan dalam kegiatan sekolah7. Penjelasan tersebut juga sejalan dengan tujuan ekstrakurikuler karate di Dojo Cakrawala yaitu mengembangkan perkaratean, mendukung karate di Kota Malang, beraktivitas fisik dengan berkarate artinya sama dengan olahraga supaya dapat meningkatkan kesehatan jasmani dan rohani dengan begitu dapat menciptakan atlit-atlit terbaik di Indonesia serta dapat menguatkan karakter anak sebagai karateka melalui penerapan sumpah karate .

Peneliti memilih ekstrakurikuler karate sebagai bahan studi kasus yang diangkat oleh peneliti bermaksud untuk meneliti dojo cakrawala yang dinaungi oleh FORKI (Federasi Olahraga Karatedo Indonesia).Lokasi latihan Dojo Cakrawala Institute Karate-Do Indonesia (INKAI) berada di Kantor Kelurahan Balearjosari yang

\footnotetext{
"Queen Elvina Sevtivia Asrivi: Implementasi Pramuka Sebagai Ekstrakurikuler Wajib Kurikulum 2013 Sekolah Dasar 255 IMPLEMENTASI PRAMUKA SEBAGAI EKSTRAKURIKULER WAJIB KURIKULUM 2013 SEKOLAH DASAR” 2 (2019): 255-68.
} 
beralamatkan di Jl. Raya Balearjosari No.9 Kota Malang.

Melihat adanya antusiasme anak sekolah dasar dalam melakukan kegiatan fisik secara tatap muka di masa pandemi membuat peneliti tertarik untuk meneliti pada fenomena ini. Walaupun ada larangan dari pemerintahh untuk mentiadakan kegiatan yang sifatnya berkumpul antusias wali murid, guru dan siswa sangat terlihat dengan adanya kepercayaan mereka terhadap Corona tidak untuk ditakuti dan kesadaran mereka akan kesehatan didapat dengan menambah imun tubuh melalui kegiatan karate.

Realita mengenai adanya latihan ekstrakurikuler diluar sekolah di masa pandemi ini menarik untuk dikaji dengan prespektif sosiologi fungsionalis dengan pendekatan teori Talcott Parsons $^{8}$ yang merancang skema (AGIL)9 . Berdasarkan teori tersebut jika dikaitkan dengan kebijakan pembelajaran secara daring yang mengharuskan siswa belajar secara daring baik itu pembelajaran di sekolah maupun ekstrakurikuler diluar sekolah terdapat fungsional dan disfungsional antara keadaan sistem yang tidak diinginkan dengan kenyataan yang ada.

Penelitian ini dilakukan guna mengetahui dampak dari kebijakan pembelajaran secara daring bagi siswa

\footnotetext{
${ }^{8}$ George Ritzer and Douglas J Goodman, "Teori Sosiologi, Dari Teori Sosiologi Klasik Sampai Perkembangan Mutakhir Teori Sosial Post Modern, Terj," Nurhadi, Yogyakarta: Kreasi Wacana, 2009.

9 George Ritzer, “Teori Sosiologi Modern,” 2004. 1o Trista Hollweck, "Robert K. Yin. (2014). Case Study Research Design and Methods (5th Ed.). Thousand Oaks, CA: Sage. 282 Pages.," The Canadian Journal of Program Evaluation, 2016, https://doi.org/10.3138/cjpe.30.1.108.
}

dan orang tua serta efektifitasnya ekstrakurikuler diluar sekolah terhadap anak sekolah dasar. Metode yang digunakan dalam penelitian ini menggunakan metode kualitatif dengan pendekatan studi kasus ${ }^{10}$. Data diperoleh dengan analisis metode participant, observasi, wawancara dan dokumentasi ${ }^{11}$. Kemudian peneliti menganalisis data menggunakan triangulasi sumber data ${ }^{12}$. Unit analisisnya adalah guru, orang tua dan siswa di perguruan dojo cakrawala. Analisis pengolahan data setelah melakukan pengumpulan data menurut miles dan Huberman ${ }^{13}$.

Dewasa ini masalah yang disorot selain masalah kesehatan di masa pandemi ini adalah masalah pendidikan yang dijumpai pada banyak negara. Krisis dalam bidang pendidikan adalah salah satu tema yang hangat dibicarakan selama pandemi covid-19 adanya sekolah daring menimbulkan polemik yang hampir sama dirasakan oleh tenaga pendidik, murid maupun orang tua. Penelitian dimasa pandemi banyak dilakukan seperti penelitian pada dampak media yang memberitakan covid-19 secara masif yang membuat masyarakat tertekan secara psikologis ${ }^{14}$. Dampak pandemi ini selain membuat masyarakat merasa tertekan dalam segi psikologis masyarakat harus dihadapkan pada

" Lexy J. Moleong, "Metodologi Penelitian Kualitatif (Edisi Revisi)," in PT. Remaja Rosda Karya, 2017.

${ }^{12}$ Moleong.

13 Matthew B Miles and Michael A. Huberman, Analisis Data Kualitatif: Buku Sumber Tentang Metode-Metode Baru, Universitas Indonesia_UI Press, 2012.

14 Kevin Stainback, Brittany N. Hearne, and Monica M. Trieu, "COVID-19 and the 24/7 News Cycle: Does COVID-19 News Exposure Affect Mental Health?," Socius 6 (2020), https://doi.org/10.1177/2378023120969339. 
kendala seperti tuntutan dalam pembelajaran online yaitu mengikuti perkembangan jaman dengan menggunakan teknologi, memasang wifi dirumah Orang tua harus pintar membagi waktu antara kerja dan mendampingi belajar anak, guru memiliki jam kerja yang bertambah $\mathrm{dll}^{15}$. Selain kendala diatas peran orang tua di masa Pandemi covid-19 ini semakin bertambah seperti sebagai pendidik, penjaga dan pengawas, pencari nafkah $\mathrm{dll}^{16}$. Adaptasi guru, orang tua dan siswa dalam menghadapi situasi dan kondisi pandemi sangat kompleks belum lagi siswa yang tidak senang dengan adanya sekolah daring dan lebih senang sekolah luring ${ }^{17}$.

Berdasarkan hal tersebut, penelititian ini dinilai penting untuk dilakukan guna menambah sumbangsih pemikiran dan memberi solusi bagi orang tua, guru dan anak sekolah dasar dalam mengarahkan anak dalam kegiatan yang positif. Terlebih peneliti berharap dengan adanya penelitian ini dapat sebagai rujukan bagi pemerintahh dalam membuat kebijakan mengenai social distancing sehingga kegiatan yang sifatnya positif dapat diberi kemudahan dan disupport agar anak sekolah dasar tetap eksis dalam kondisi apapun sehingga generasi muda tetap unggul dalam karakter maupun prestasi. Oleh karena itu peneliti mengusung tema penelitian dengan judul implikasi ekstrakurikuler karate pada anak sekolah dasar di masa pandemi covid-19.

\section{HASIL DAN PEMBAHASAN}

\footnotetext{
15 Agus Purwanto et al., "Studi Eksploratif Dampak Pandemi COVID-19 Terhadap Proses Pembelajaran Online Di Sekolah Dasar," EduPsyCouns: Journal of Education, Psychology and Counseling 2, no. 1 (2020): 1-12, https://ummaspul.ejournal.id/Edupsycouns/article/view/397.

${ }^{16}$ Euis Kurniati, Dina Kusumanita Nur Alfaeni, and Fitri Andriani, “Analisis Peran Orang Tua
}

\section{Dampak Kebijakan Daring Di Masa Pandemi}

Kurikulum sekolah dasar di Indonesia masih menekankan pada keberhasilan pembelajaran pengetahuan dasar secara umum dari bidang studi mipa, ips dan bahasa, dengan kompleksnya bahan pembelajaran yang harus di kuasai siswa sekolah dasar, siswa membutuhkan sistem pembelajaran secara jelas untuk memahami materi yang harus mereka kuasai pada jenjang sekolah dasar. Namun, hal itu seperti utopia karena antara tujuan dan proses pembelajaran dilapangan banyak yang timpang terlebih proses belajar mengajar pada saat pandemi dengan berbagai macam polemik yang dialami oleh siswa, guru dan orang tua dalam menghadapi kebaruan proses belajar dari luring menjadi daring. Merespons surat edaran dari kemendikbud mengenai pembelajaran secara online, kepala sekolah di Kota Malang sebagian besar menanggapi kebijakan tersebut dengan membuat kebijakan untuk meliburkan kegiatan belajar mengajar dan ekstrakurikuler di lingkungan sekolah. Kebijakan meliburkan kegiatan tatap muka secara masif di hampir semua sekolah di Kota Malang membuat pro dan kontra

\footnotetext{
Dalam Mendampingi Anak Di Masa Pandemi Covid-19," Jurnal Obsesi : Jurnal Pendidikan Anak Usia Dini 5, no. 1 (2020): 241, https://doi.org/10.31004/obsesi.v5i1.541.

17 Priarti Megawanti, Erna Megawati, and Siti Nurkhafifah, "Persepsi Peserta Didik Terhadap PJJ Pada Masa Pandemi COVID-19," Jurnal Ilmiah Pendidikan 7, no. 2 (2020): 75-82.
} 
untuk guru, siswa dan orang tua. Hal tersebut bisa terjadi karena banyaknya dampak yang harus ditanggung siswa dan guru pada saat sekolah daring. Seperti halnya tugas sebagai pendidik untuk mencerdaskan anak bangsa menjadi terhambat karena kurang siapnya guru dalam mempersiapkan proses belajar dan mengajar secara daring. Jika dilihat dari sistem pengajaran daring yang ajek selama lima hari dalam satu minggu tanpa adanya tatap muka membuat siswa kesulitan dalam mengikuti materi pelajaran dalam sekolah.

Hasil wawancara informan:s

" Saya tidak suka sebenarnya melakukan sekolah daring selain membuat kami tidak bisa

bertemu dengan teman, kami kesulitan dalam memahami pelajaran di sekolah terlebih pelajaran matematika kami sangat tidak mengerti karena penjelasan yang kurang detail dari guru kami, di sisi lain saya bingung untuk bertanya kepada siapa karena orang tua juga gaptek (gagap teknologi) dan kurang memahami materi pelajaran yang saat ini diajarkan oleh guru kami" 18

Jika dilihat dari pernyataan informan yang menyatakan bahwa ada hambatan mengenai kurangnya pemahaman dalam bidang matematika ini juga di rasakan oleh 3 informan yang lain yang merasa mengerjakan PR dengan seadanya karena matematika adalah ilmu pasti dimana siswa tidak bisa menerka-nerka jawaban dari tugas.

\footnotetext{
18 Hasil wawancara dengan U sebagai siswa di Dojo Cakrawala

19 Hasil wawancara dengan U sebagai siswa di Dojo Cakrawala
}

Siswa juga mengeluh karena sakit pada mata dan pusing seperti yang dituturkan informan

" saya merasa mata saya sakit ketika saya harus melihat hp secara terus menerus bahkan sekarang saya sudah minus." ${ }^{19}$ Pernyataan lain di jelaskan oleh informan

" kalau saya lebih ke pusing karena bingung tidak paham dengan materinya disisi lain saya harus mengerjakan PR dari bu guru”

$$
\text { Pada awal penerapan }
$$

pembelajaran daring yang baru dilakukan pada saat pandemi ini membuat siswa dan orang tua menjadi kesusahan dan terbebani dengan tantangan dan tuntutan baru. Sehingga kemendikbud menerbitkan kurikulum darurat untuk merespon permasalahan yang terjadi dari dampak kebijakan sekolah daring. Dengan menerbitkan surat edaran nomor $719 / \mathrm{P} / 2020{ }^{20}$ yang berisi tentang kurikulum khusus.Dengan demikian harapan pemerintahh dengan adanya kurikulum khusus ini siswa dapat lebih ringan dalam belajar sehingga pemahaman dan penerimaan materi selama proses pembelajaran daring dapat berjalan efektif. Proses belajar dan mengajar sekarang tidak difokuskan pada penguasaan kemampuan kognitif saja dengan adanya penyederhanaan kurikulum guru tidak hanya menilai dengan menggunakan asesmen kognitif saja melainkan juga penilaian pada aspek psikologis dan afektif.

Pembelajaran secara daring sering kali membuat siswa merasakan kurang antusias karena siswa kesulitan

\footnotetext{
2o "Kementerian Pendidikan Dan Kebudayaan " Republik Indonesia," accessed March 1, 2021, https://www.kemdikbud.go.id/main/blog/2020 /o8/kemendikbud-terbitkan-kurikulumdarurat-pada-satuan-pendidikan-dalamkondisi-khusus.
} 
dalam memahami pelajaran dengan baik terlebih ketika penyampaian pembelajaran sekarang menggunakan media online seperti google classroom, google meet dll yang membuat siswa kebingungan dalam memahami dan mengerjakan tugas yang sudah diberikan guru melalui media google classroom atau media lainnya. Permasalahan seperti ini sudah direspon pemerintah melalui kebijakan pemangkasan kompetensi dasar namun faktanya dilihat dari hasil wawancara dengan siswa SD mereka masih kesulitan dalam mengikuti pelajaran secara daring karena materi yang disampaikan guru terutama materi matematika sangat susah untuk dipahami.

Jika dilihat dari persoalan mengenai sulitnya memahami materi pelajaran yang dijelaskan guru secara daring membuat asesmen kognitif siswa mengalami penurunan yang signifikan. Akan lebih baik apabilah pemerintahh dapat menggeser fokus pembelajaran sekolah dasar dengan penguasaan pada bidang non-kognitif melalui kegiatan ekstrakurikuler atau kegiatan seni lainnya. Apabila penekanan pendidikan pada saat darurat seperti situasi pandemi ini fokus pada nilai kognitif saja akan sangat disayangkan apabila proses belajar dan mengajar dilapangan menjadi suatu beban belajar dan mengajar bagi guru, siswa dan orang tua. Jika pendidikan pada saat darurat difokuskan pada bakat dan minat anak sekolah dasar secara tepat maka pendidikan dalam masa pandemi ini akan berhasil mengingat anak sekolah dasar dapat belajar melalui penyaluran minat dan bakatnya secara tepat dan

${ }^{21}$ Rima Trianingsih, "Pengantar Praktik Mendidik Anak Usia Sekolah Dasar," Al Ibtida: Jurnal Pendidikan Guru MI 3, no. 2 (2016): 197, https://doi.org/10.24235/al.ibtida.snj.v3i2.88o. terstruktur. Jadi dapat kami rekomendasikan bahwa pembelajaran pada saat pandemi ini salah satunya dapat difokuskan pada bidang ekstrakurikuler sesuai dengan bakat dan minat, dengan begitu anak terbebani dengan beban mata pelajaran yang mereka kurang kuasai ${ }^{21}$.

Masalah yang timbul dari belajar daring tidak hanya dari persoalan mengenai akademik saja namun ada persoalan lain dimana anak sekolah dasar yang merasa tidak bisa beraktivitas dengan baik karena bosan jika harus dirumah saja dan mereka menginginkan ada sekolah yang dilakukan secara tatap muka dalam 1 minggu sekali atau satu minggu 2 kali. Pernyataan ini di dasari dengan pernyata informan

"Saya tidak terlalu takut dengan corona selama kita bisa menjaga diri dengan baik, olahraga, cuci tangan dan memakai masker. Karena kalau sekolah dibikin 1 minggu sekali atau 2 minggu sekali saya merasa santai-santai saja dengan corona"22.

Kebijakan

mengenai pembelajaran daring merupakan kebijakan yang tepat jika dalam situasi pandemi covid-19 seperti saat ini. Namun, akan lebih tepat lagi apabila kebijakan pembelajaran daring ini tidak dipukul rata dalam semua kegiatan pembelajaran. Jika kegiatan pembelajaran secara daring ini di pukul rata pada kegiatan pembelajaran yang sifatnya membuat mental, psikis dan kesehatan siswa menjadi lebih baik dan lebih sehat mungkin kebijakan ini dapat dipertimbangkan atau dikaji ulang untuk membuat peraturan baru semisal pembelajaran tatap muka untuk

\footnotetext{
${ }^{22}$ Hasil wawancara dengan $U$ sebagai siswa di Dojo Cakrawala
} 
pelajaran PJOK atau pelajaran ekstrakurikuler di dalam sekolah maupun diluar sekolah, terkhusus untuk anak sekolah dasar yang notabene kesusahan apabila harus melakukan aktivitas fisik secara individu.

Pembelajaran secara daring pada saat pandemi memiliki dampak positif dan negatif terhadap psikis, psikologi, fisik, mental, waktu dll. Namun, semua hal ini bisa diatasi dengan peran orang tua dan guru dalam mengarahkan dan memotivasi anak untuk bijak dalam mengontrol diri dan memanfaatkan waktu dengan baik. Peran orang tua dalam pembelajaran secara daring adalah sebagai pendamping sekaligus guru bagi anak mereka sendiri dalam mengarahkan dan mendampingi pengerjaan tugas yang sudah diberikan guru di sekolah. Orang tua juga berfungsi sebagai pengontrol anak agar dapat memanagement waktu dengan baik seperti yang dituturkan oleh informan $\mathrm{Bu} \mathrm{Y}{ }^{23}$

“ Alhamdulilah mbak pekerjaan saya fleksibel dan bisa dikerjakan dirumah jadi saya bisa mengontrol dan mengarahkan anak saya dalam mengerjakan tugas sekolah. Tapi ya begitu biasanya saya mengantar anak sekolah terus saya bekerja sekarang saya harus pintar-pintar memanajemen waktu agar bisa mendampingi anak saya mengerjakan tugas dan bekerja disela-sela mendampingi anak. Susahnya saya sekarang itu harus sering mengomeli karena anak saya sekarang kecanduan bermain gawai sehingga saya harus sering-sering mengingatkan."

Adanya orang tua sebagai ibu rumah tangga atau orang tua yang bekerja dirumah dapat membantu

\footnotetext{
23 Hasil wawancara dengan $\mathrm{Bu} \mathrm{Y}$ sebagai orangtua/walimurid siswa di Dojo Cakrawala
}

mengarahkan anak untuk lebih produktif sesuai umurnya. Namun, berbeda jika anak yang memiliki orang tua yang sama-sama bekerja banyak anak menjadi tidak terarahkan tidak mengerjakan tugas atau bingung dalam menggerjakan tugas dll. Banyak kasus yang terjadi akibat dari kebijakan sekolah daring. Namun, orang tua dari anak-anak yang latihan di Dojo Cakrawala merasa tidak terlalu dirugikan dalam konteks sebagai pendamping belajar anak karena kebanyakan dari orang tua siswa di Dojo Cakrawala adalah ibu rumah tangga atau orang tua yang memiliki pekerjaan yang fleksible sehingga dapat memanajemen waktu untuk mendampingi anak dalam belajar dan mengikuti ekstrakurikuler yang diminati. Sehingga bisa dikatakan bahwa anak-anak yang latihan di Dojo Cakrawala tergolong anak-anak yang bisa menyalurkan energi mereka dengan melakukan hal positif seperti beraktivitas sesuai kegemaran mereka. Dengan adanya pengarahan yang tepat dari orang tua dan guru dapat membuat anak-anak sekolah dasar tidak kecanduan handphone yang berlebihan hal ini didasari dari hasil wawancara dari berbagai murid dan orang tua yang mengatakan bahwa hanya memberi waktu $1 / 2$ jam untuk bermain gawai dalam satu minggu beberapa kali. Selebihnya orang tua mengarahkan untuk mengikuti ekstrakurikuler yang diminati anak atau mengikuti les tambahan untuk membantu pemahaman anak dalam memahami materi pelajaran di sekolah.

Tugas orang tua dan guru selain mengarahkan dalam bidang akademis peran keduannya juga sangat berpengaruh pada eksistensi mereka. 
Peran guru karate di dojo cakrawala yaitu membentuk pribadi anak sesuai dengan sumpah karate agar dapat berprestasi secara akademik maupun non akademik. Sedangkan peran orang tua jika mempunyai anak yang aktif dengan kegiatan fisik orangtua dapat menjaga pola makan sehingga asupan gizi anak bisa tercukupi dengan begitu mereka dapat kuat,sehat dan energik ${ }^{24}$. Perkembangan fisik dan motorik anak adalah sesuatu yang tidak dapat terpisahkan. Perkembangan fisik anak akan berpengaruh pada gerak motoriknya maka dari itu kegiatan yang sifatnya melatih fisik anak sebaiknya tetap dilakukan. Pertumbuhan anak tidak jauh dari perkembangan secara fisik dan motorik karena keduanya saling melengkapi. Pertumbuhan secara fisik dapat diamati melalui tinggi dan bentuk tubuh, sedangkan pertumbuhan motoric dapat diamati dengan kemampuan anak dalam menyeimbangkan diri ketika berlari atau melakukan aktifitas lainnya ${ }^{25}$. Perkembangan fisik dinilai penting karena apabila anak melakukan kegiatan fisik dengan baik secara otomatis perkembangan motoriknya juga baik. Di usia SD ini adalah waktu yang bagus untuk mengembangkan kemampuan motorik dasar anak sehingga anak SD dapat menyeimbangkan badan, berlari, melompat, dan melempar ${ }^{26}$.

Pada usia sekolah dasar sistem motorik sangat penting untuk dilatih dengan melakukan aktivitas seperti

\footnotetext{
24 Furkan, Rusdin, and Shutan Arie Shandi, "Menjaga Daya Tahan Tubuh Dengan Olahraga Saat Pandemi Corona Covid-19," Menjaga Daya Tahan Tubuh Dengan Olahraga Saat Pandemi Corona Covid-19 5, no. 1 (2021): 424-30, http://ejournal.mandalanursa.org/index.php/JI SIP/article/view/1748.

25 Tri Murti, "Perkembangan Fisik Motorik Dan Perseptual Serta Implikasinya Pada
}

mengikuti ekstrakurikuler yang melibatkan kegiatan fisik seperti olahraga karate dapat meningkatkan perkembangan motorik. Dukungan dari wali murid dan stake holder sangat berperan penting dalam menumbuhkan semangat, kepercayaan diri anak bahwa mereka merasa didukung dengan begitu secara tidak langsung anak semakin termotivasi untuk rajin latihan dan berprestasi melalui ekstrakurikuler karate. Sehingga peran guru dan orang tua sangat berpengaruh pada minat anak dalam menyalurkan energinya untuk hal-hal positif dan eksis.

Setidaknya dalam situasi pandemi covid-19 ini anak SD bisa merasa eksis dan tidak minder dengan kemampuan mereka apabila mendapat nilai yang tidak sesuai dengan harapan mereka. Penyaluran bakat dan minat yang tepat membuat anak-anak tidak menghabiskan waktu dengan bermain tiktok atau dengan sekedar berselancar di sosial media melainkan bisa produktif dengan aktivitas yang mereka ingin kuasai dan mengerti. Dengan begitu anak-anak dapat secara optimal memanfaatkan waktu dengan bersosialisasi didunia nyata, belajar, mengasah hobi dan olahraga atau aktivitas lainnya. Sehingga anak Sekolah Dasar dapat mengeksplorasi bakat dan hobinya melalui pengarahan guru dan orang tua.

\section{Efektifitas Pelaksanaan Ekstrakurikuler Di Luar Sekolah Selama Pandemi Kebijakan}

Pembelajaran Di Sekolah Dasar," Wahana Sekolah Dasar 26, no. 1 (2018): 21-28, https://doi.org/10.17977/umo35v26i12018po21.

${ }^{26}$ Sepriadi Sepriadi, "Kontribusi Status Gizi Dan Kemampuan Motorik Terhadap Kesegaran Jasmani Siswa Sekolah Dasar,” Jurnal Keolahragaan 5, no. 2 (2017): 194, https://doi.org/10.21831/jk.v5i2.15147. 
pemerintahh secara preventif dalam pencegahan penularan covid-19 terbilang kurang dapat berjalan maksimal dan efektif pada kegiatan pembelajaran ekstrakurikuler. Dilihat dari surat edaran kebijakan peraturan wali Kota Malang nomor 30 tahun $202 \mathrm{O}^{27}$ kegiatan pada masa transisi sub a yang menyatakan semua kegiatan pembelajaran diubah

pelaksanaannya dengan melakukan pembelajarannya di rumah atau secara daring . Pasal 9 No. 7 menyebutkan bahwa sekolah atau institut pendidikan lainnya yang tidak dapat memenuhi standar protokol kesehatan dilarang untuk melakukan kegiatan secara tatap muka.

Adanya peraturan pemerintahh mengenai proses kegiatan tatap muka ini sekolah-sekolah di Kota Malang mulai menerapkan protokol kesehatan seperti penerapan protokol kesehatan. Dengan begitu apabila situasi Kota Malang berada pada zonasi hijau sekolah-sekolah siap melakukan kegiatan tatap muka dengan menerapkan prokes. Namun, faktanya orang yang terjangkit virus corona di Kota Malang mengalami peningkatan secara signifikan sehingga pemerintahh melarang kegiatan yang sifatnya berkumpul dan berisiko untuk menjadi tempat persebaran virus corona.

Namun, kebijakan permerintah yang melarang adanya kegiatan ekstrakurikuler secara tatap muka yang dikhawatirkan dapat berpotensi menimbulkan cluster corona baru ini secara tidak langsung ditepis dengan dibuktikan dari fakta selama 6 bulan Dojo Cakrawala melakukan latihan

\footnotetext{
27 Wali Kota, "Peraturan Wali Kota Malang Nomor $30 \quad$ Tahun 2020," 2020, https://covidig.hukumonline.com/wpcontent/uploads/2020/o9/peraturan_wali_kota _malang_nomor_30_tahun_2020.pdf.
}

selama tiga kali seminggu dan peserta aktif ada 20 anak dari 30 pendaftar dojo ini tetap melakukan latihan secara rutin tanpa menimbulkan cluster baru dalam dojo tersebut. Hal ini bisa terjadi karena dalam kegiatan ekstrakurikuler karate di Dojo Cakrawala tetap mematuhi protokol kesehatan serta kegiatan yang dilakukan di perguruan karate ini adalah kegiatan yang sifatnya positif dan melatih fisik. Olahraga dipercaya mampu meningkatkan imunitas tubuh, kesehatan psikis dan mental anak karena dalam kegiatan ekstrakurikuler ini anak-anak dapat melakukan kegiatan fisik yang menyenangkan sambil melakukan permainanpermainan yang sifatnya dapat membuat mereka senang sebagai bentuk rekreasi mereka setelah belajar daring. Sehingga hal-hal yang sifatnya positif dan mampu menambah kekebalan imunitas tubuh dan kesehatan jiwa baik secara fisik dan rohani ini sangat mampu untuk menjadikan anak terhindar dari persebaran virus corona hal ini bisa dilihat dari kutipan penelitian ${ }^{28}$

British Journal of Sprots Medicine, meneliti bahwa orang yang melakukan olahraga lima hari dalam seminggu dapat memiliki risiko sebesar 46\% lebih kecil untuk terinfeksi virus flu atau gangguan pernapasan. Namun, hasil penelitian menunjukkan orang yang lebih bugar sekalipun dapat terkena gejala flu namun tingkat kesembuhannya cepat.Sedangkan studi besar membuktikan bahwa orang yang berolahraga dalam 1 minggu 3 kali dapat mencegah kematian ketika ada wabah flu Hong Kong. Berolahraga dengan

\footnotetext{
${ }^{28}$ Furkan, Rusdin, and Shandi, "Menjaga Daya Tahan Tubuh Dengan Olahraga Saat Pandemi Corona Cosvid-19."
} 
cukup dalam satu minggu dapat meminimalisir resiko meninggal ${ }^{29}$.

Sehingga studi besar diatas dapat berkolerasi dengan kegiatan ekstrakurikuler di tengah wabah pandemi yang melibatkan kegiatan secara fisik seperti olahraga secara cukup yaitu tiga kali satu minggu dapat membuat tubuh tetap bugar. Kegiatan ekstrakurikuler yang melibatkan aktivitas secara fisik atau olahraga bagus untuk kekebalan tubuh dari serangan virus, olahraga juga mampu meningkatkan imunitas tubuh sehingga tubuh dapat memerangi Covid-19. Olahraga melalui ekstrakurikuler karate diluar sekolah sangat menyenangkan dan dapat membuat anak-anak menjadi lebih sehat menurut informasi dari salah satu informan.

" Saya suka mengikuti latihan karate karena saya senang dan saya bisa lebih sehat dengan berolahraga satu minggu tiga kali, karena latihan karate menyenangkan saya jadi senang dan tidak mudah sakit" 30

Kegiatan ekstrakurikuler karate secara tatap muka di masa pandemi memang berisiko dalam penularan Covid-19 yang cepat menyebar. Namun, untuk mencegah penyebaran Covid-19 yang berpotensi menurunkan aktivitas fisik harian. Saya merekomendasikan ini dengan sangat disayangkan karena olahraga dengan cukup dapat membantu memerangi penyakit dengan meningkatkan sistem kekebalan kita dan menangkal beberapa penyakit penyerta seperti depresi dan penyakit dalam yang sifatnya serius sehingga mudah tertular virus covid-19 ${ }^{31}$. Namun, apabila merasa tidak enak badan, flu,

\footnotetext{
29 Furkan, Rusdin, and Shandi.

30 Hasil wawancara dengan I sebagai siswa di Dojo Cakrawala

${ }^{31}$ Jeffrey A. Woods et al., "The COVID-19

Pandemic and Physical Activity," Sports
}

panas, batuk dan pusing sangat tidak dianjurkan untuk memaksakan diri dalam melakukan aktivitas fisik diluar rumah.

\section{B. SIMPULAN}

Aktivitas non-kognitif seperti ekstrakurikuler merupakan solusi untuk anak dalam meningkatkan sistem motorik dan melatih fisik anak. Lazimnya kegiatan seni atau lintas minat anak diwadahi di sekolah dalam ekstrakurikuler. Namun, dimasa pandemi ini kegiatan seperti ekstrakurikuler disekolah dilakukan secara daring. Sehingga fungsi dari ekstrakurikuler sebagai ajang untuk mengembangkan kemampuan yang terutama berfokus pada penambahan imun, melatih fisik, motorik dan karakter siswa serta berbagai keterampilan hidup lainnya tidak dapat terpenuhi karena aktivitas ekstrakurikuler dilakukan secara daring. Di satu sisi kegiatan ekstrakurikuler yang dilakukan secara tatap muka memang lebih efektif dalam pencapaian tujuan dari ekstrakurikuler. Namun, disisi lain ekstrakurikuler secara tatap muka memiliki resiko dalam penularan covid-19, sedangkan apabila anak sekolah dasar jika hanya diam di rumah tanpa melakukan hal positif akan memungkinkan mereka melakukan hal negatif seperti menghabiskan waktu untuk tidur berlebihan, bermain gawai atau sekedar bermain dengan teman sebaya. Dengan begitu rekomendasi yang tepat dalam situasi pandemi seperti ini baiknya peraturan pemerintahh mengenai ekstrakurikuler dapat lebih lunak supaya anak-anak

Medicine and Health Science 2, no. 2 (June 2020): 55-64, https://doi.org/10.1016/j.smhs.2020.05.006. 
dapat memanfaatkan waktu luang untuk kegiatan yang lebih positif mengingat keefektifan pembelajaran secara daring kurang maksimal sehingga pembelajaran melalui ekstrakurikuler seperti karate dapat membuat mental, fisik, psikis, motorik, kesehatan anak dapat berjalan secara optimal, positif, eksis dan berprestasi.

\section{DAFTAR PUSTAKA}

Furkan, Rusdin, and Shutan Arie Shandi. "Menjaga Daya Tahan Tubuh Dengan Olahraga Saat Pandemi Corona Covid-19." Menjaga Daya Tahan Tubuh Dengan Olahraga Saat Pandemi Corona Covid-19 5, no. 1 (2021): 42430.

http://ejournal.mandalanursa.org/i ndex.php/JISIP/article/view/1748.

Hollweck, Trista. "Robert K. Yin. (2014). Case Study Research Design and Methods (5th Ed.). Thousand Oaks, CA: Sage. 282 Pages." The Canadian Journal of Program Evaluation, 2016.

https://doi.org/10.3138/cjpe.30.1.108

Kemendikbud. "SE Mendikbud: Pembelajaran Secara Daring Dan Bekerja Dari Rumah Untuk Mencegah Penyebaran Covid-19." Kementerian Pendidikan dan Kebudayaan Republik Indonesia, 2020.

https://www.kemdikbud.go.id/mai n/blog/2020/o3/se-mendikbudpembelajaran-secara-daring-danbekerja-dari-rumah-untukmencegah-penyebaran-covidı.

"Kementerian Pendidikan Dan Kebudayaan » Republik Indonesia." Accessed March 1, 2021. https://www.kemdikbud.go.id/mai n/blog/2020/o8/kemendikbudterbitkan-kurikulum-darurat- pada-satuan-pendidikan-dalamkondisi-khusus.

Kota, Wali. "Peraturan Wali Kota Malang Nomor 30 Tahun 2020," 2020.

https://covidı.hukumonline.com/ wpcontent/uploads/2020/o9/peratura n_wali_kota_malang_nomor_30_ta hun_2020.pdf.

Kurniati, Euis, Dina Kusumanita Nur Alfaeni, and Fitri Andriani. "Analisis Peran Orang Tua Dalam Mendampingi Anak Di Masa Pandemi Covid-19." Jurnal Obsesi : Jurnal Pendidikan Anak Usia Dini 5, no. 1 (2020): 241. https://doi.org/10.31004/obsesi.v5i1 .541 .

Megawanti, Priarti, Erna Megawati, and Siti Nurkhafifah. "Persepsi Peserta Didik Terhadap PJJ Pada Masa Pandemi COVID-19." Jurnal Ilmiah Pendidikan 7, no. 2 (2020): 75-82.

Miles, Matthew B, and Michael A. Huberman. Analisis Data Kualitatif: Buku Sumber Tentang Metode-Metode Baru. Universitas Indonesia_UI Press, 2012.

Moleong, Lexy J. "Metodologi Penelitian Kualitatif (Edisi Revisi)." In PT. Remaja Rosda Karya, 2017.

Murti, Tri. "Perkembangan Fisik Motorik Dan Perseptual Serta Implikasinya Pada Pembelajaran Di Sekolah Dasar." Wahana Sekolah Dasar 26, no. 1 (2018): 21-28. https://doi.org/10.17977/umo35v26i 12018 po21.

Pendidikan Dasar, Jurnal, Jurnal Tunas Nusantara, and Queen Elvina Sevtivia Asrivi. "Queen Elvina Sevtivia Asrivi : Implementasi Pramuka Sebagai Ekstrakulikuler Wajib Kurikulum 2013 Sekolah Dasar $255 \quad$ IMPLEMENTASI PRAMUKA SEBAGAI 
EKSTRAKURIKULER WAJIB

KURIKULUM 2013 SEKOLAH

DASAR" 2 (2019): 255-68.

"Pengumuman Mendadak Jokowi Yang Kejutkan Pasien Positif Corona... Halaman All - Kompas.Com." Accessed March 1, 2021. https://nasional.kompas.com/read /2020/03/04/o8051361/pengumuma n-mendadak-jokowi-yang-

kejutkan-pasien-positifcorona?page $=$ all.

Presiden Republik Indonesia. "Peraturan Pemerintahh Nomor 21 Tahun 2020 Tentang Pembatasan Sosial Berskala Besar Dalam Rangka Percepatan Penanganan Coronavirus Disease 2019/COVID19" 2019, no. 022868 (2020): 8.

Purwanto, Agus, Rudy Pramono, Masduki Asbari, Priyono Budi Santoso, Laksmi Mayesti Wijayanti, Chi Hyun Choi, and Ratna Setyowati Putri. "Studi Eksploratif Dampak Pandemi COVID-19 Terhadap Proses Pembelajaran Online Di Sekolah Dasar." EduPsyCouns: Journal of Education, Psychology and Counseling 2, no. 1 (2020): 1-12. https://ummaspul.ejournal.id/Edupsycouns/article/vie w/397.

Ritzer, George. “Teori Sosiologi Modern," 2004.

Ritzer, George, and Douglas J Goodman. "Teori Sosiologi, Dari Teori Sosiologi Klasik Sampai Perkembangan Mutakhir Teori Sosial Post Modern, Terj." Nurhadi, Yogyakarta: Kreasi Wacana, 2009.

Sepriadi, Sepriadi. "Kontribusi Status Gizi Dan Kemampuan Motorik Terhadap Kesegaran Jasmani Siswa Sekolah Dasar.” Jurnal Keolahragaan 5, no. 2 (2017): 194. https://doi.org/10.21831/jk.v5i2.1514 7 .
Stainback, Kevin, Brittany N. Hearne, and Monica M. Trieu. "COVID-19 and the 24/7 News Cycle: Does COVID-19 News Exposure Affect Mental Health?" Socius 6 (2020). https://doi.org/10.1177/23780231209 69339.

Sutisna, Oteng. "Landasan Teori Kegiatan Ekstrakulikuler." Journal of Chemical Information and Modeling 53, no. 9 (2019): 1689-99.

Trianingsih, Rima. "Pengantar Praktik Mendidik Anak Usia Sekolah Dasar." Al Ibtida: Jurnal Pendidikan Guru MI 3, no. 2 (2016): 197. https://doi.org/10.24235/al.ibtida.s nj.v3i2.88o.

Woods, Jeffrey A., Noah T. Hutchinson, Scott K. Powers, William O. Roberts, Mari Carmen GomezCabrera, Zsolt Radak, Istvan Berkes, et al. "The COVID-19 Pandemic and Physical Activity." Sports Medicine and Health Science 2, no. 2 (June 2020): $55^{-64}$. https://doi.org/10.1016/j.smhs.2020 .05.006.

Yunus, Nur Rohim, and Annissa Rezki. "Kebijakan Pemberlakuan Lock Down Sebagai Antisipasi Penyebaran Corona Virus Covid19." SALAM: Jurnal Sosial Dan Budaya Syar-I 7, no. 3 (2020): 22738.

https://doi.org/10.15408/sjsbs.v7i3.1 5083.

\section{Internet}

Kementerian Pendidikan dan Kebudayaan, R. I. (2020). Surat Edaran Nomor 4 Tahun $2020 \quad$ Tentang Pelaksanaan Kebijakan Pendidikan Dalam Masa Darurat Penyebaran Coronavirus Disease (COVID19). 1-3.

Kementerian Pendidikan dan Kebudayaan Republik Indonesia. (2020). 
Surat Edaran Menteri Pendidikan

dan Kebudayaan Republik Indonesia Nomor 35952/MPK.A/HK/2020. 1-2.

Panduan Penyelenggaraan Pembelajaran pada Tahun Ajaran dan Tahun Akademik Baru di Masa Covid-

19 .https://www.kemdikbud.go.id/main /blog/2020/08/penyesuaiankeputusan-bersama-empatmenteri-tentang-panduanpembelajaran-di-masa-pandemicovid19. 15 juni 2020

\section{Wawancara}

U, (siswa), wawancara oleh Panca Kumala Dewi Universitas Negeri Malang 27 Februari 2021.

I, (siswa), wawancara oleh Panca Kumala Dewi Universitas Negeri Malang 27 Februari 2021.

$\mathrm{Bu} Y$ (Orang Tua wali murid), wawancara oleh Panca Kumala Dewi Universitas Negeri Malang 27 Februari 2021. 